
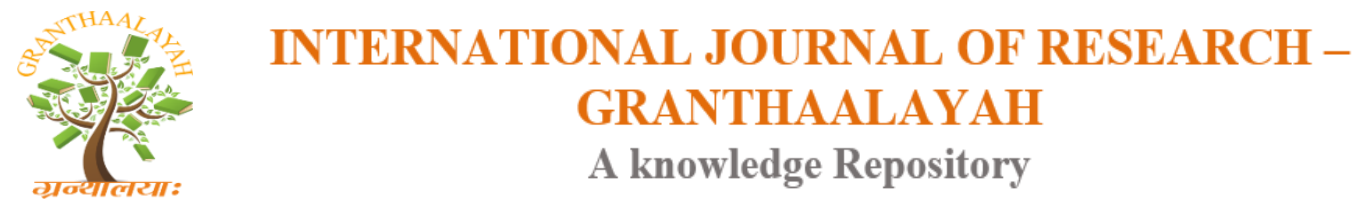

Management

\title{
TWO-WHEELER CONSUMERS' BEHAVIOUR TOWARDS CUSTOMER SATISFACTION
}

\author{
Prof. Mohd. Akbar Ali Khan ${ }^{1}$, Datrika Venkata Madhusudan Rao ${ }^{2}$ \\ ${ }^{1}$ Research Guide, Former Vice-Chancellor-Telangana University, Telangana State Presently, \\ Professor \& Additional Director, DDE, Maulana Azad National Urdu University, Gachibowli, \\ Hyderabad-32, Telangana State \\ ${ }^{2}$ Research Scholar (PhD) Rayalaseema University, Kurnool
}

\begin{abstract}
This original exploratory study was to examine the impact of select exogenous and demographic variables on Customer Satisfaction. As per ACMA May month data, top four brands, namely Hero, Bajaj, Honda and TVS brands were selected for study and 600 two-wheeler consumers' samples collected, using random sampling in Hyderabad. The data were analysed with descriptive statistics, and non-parametric tests, to know the impact of independent and demographic variables on customer satisfaction and found no impact, further given different implications.

Keywords: Customer Satisfaction; Joint Venture Preference; Heritage Design; Technology Development; Safety Features; Corporate Social Responsibility.

Cite This Article: Prof. Mohd. Akbar Ali Khan, and Datrika Venkata Madhusudan Rao. (2018). "TWO-WHEELER CONSUMERS' BEHAVIOUR TOWARDS CUSTOMER SATISFACTION." International Journal of Research - Granthaalayah, 6(2), 13-31. https://doi.org/10.5281/zenodo.1185611.
\end{abstract}

\section{Introduction}

Automotive Industry, globally, as well as in India, is one of the key sectors of the economy due to its strong forward and backward linkages. In a Global Competitiveness Survey of 104 countries, India ranked only 55th. To address this issue, Competitive landscape of the industry was developed using the Porter (1990) Diamond Framework by India Brand Equity Foundation (2006); Automotive Mission Plan 2006-16 and Automotive Mission Plan 2016-26 - A Curtain Raiser.

\subsection{Two-Wheeler Industry - Indian Scenario}

The Indian two-wheeler industry attracted worldwide attention after the major reforms (LPG) in 1991 and after, even though it had its beginnings in the late fifties when Enfield set up its plant to 
make 'bullet' motorcycles. A number of foreign players entered the market and prominent among them were Suzuki, Honda, Yamaha and Kawasaki in Joint Venture route, later on some break-ups also observed. Motorcycles became the largest segment (more than 80 per cent) in the two-wheeler industry (refer Table 1), with different segments. The break-ups reasons varied, as a result, Indian companies were forced to invest heavily in research and development for manufacturing indigenously developed models. The Auto market changed dramatically in terms of technology also viz., four-stroke motorcycles, fuel injection motors, looks, benefitted features, power, mileage (fuel economy), environmental compliance, performance, comfort, alternative fuel, and electric two-wheelers. The industry is growing every year due to inadequate public transport, better financing, availability of models, increasing urbanization and increase in skilled youth population and per capita income.

Table 1: Automobile Domestic Sales Trends

\begin{tabular}{|c|c|c|c|c|c|c|c|c|c|c|c|c|}
\hline $\begin{array}{l}\text { Cate } \\
\text { gory }\end{array}$ & $\begin{array}{l}2005 \\
-06\end{array}$ & 06-07 & $\begin{array}{l}07- \\
08\end{array}$ & $\begin{array}{l}08- \\
09\end{array}$ & 09-10 & 10-11 & 11-12 & $12-13$ & 13-14 & 14-15 & $15-16$ & 16-17 \\
\hline $\begin{array}{l}\text { Pass. } \\
\text { Vehi }\end{array}$ & $\begin{array}{l}1,143 \\
.076\end{array}$ & $\begin{array}{l}1,379, \\
979\end{array}$ & $\begin{array}{l}1,549 \\
, 882\end{array}$ & $\begin{array}{l}1,552 \\
, 703\end{array}$ & $\begin{array}{l}19,51, \\
333\end{array}$ & $\begin{array}{l}25,01, \\
542\end{array}$ & $\begin{array}{l}26,29, \\
839\end{array}$ & $\begin{array}{l}26,65, \\
015\end{array}$ & $\begin{array}{l}25,03, \\
509\end{array}$ & $\begin{array}{l}26,01, \\
111\end{array}$ & $\begin{array}{l}27,89, \\
208\end{array}$ & $\begin{array}{l}30,46, \\
727\end{array}$ \\
\hline $\begin{array}{l}\text { Com. } \\
\text { Vehi }\end{array}$ & $\begin{array}{l}351,0 \\
41\end{array}$ & $\begin{array}{l}467,7 \\
65\end{array}$ & $\begin{array}{l}490,4 \\
94\end{array}$ & $\begin{array}{l}384,1 \\
94\end{array}$ & $\begin{array}{l}5,32,7 \\
21\end{array}$ & $\begin{array}{l}6,84,9 \\
05\end{array}$ & $\begin{array}{l}8,09,4 \\
99\end{array}$ & $\begin{array}{l}7,93,2 \\
11\end{array}$ & $\begin{array}{l}6,32,8 \\
51\end{array}$ & $\begin{array}{l}6,14,9 \\
61\end{array}$ & $\begin{array}{l}6,85,7 \\
04\end{array}$ & $\begin{array}{l}7,14,2 \\
32\end{array}$ \\
\hline $\begin{array}{l}3- \\
\text { Wlrs }\end{array}$ & $\begin{array}{l}359,9 \\
20\end{array}$ & $\begin{array}{l}403,9 \\
10\end{array}$ & $\begin{array}{l}364,7 \\
81\end{array}$ & $\begin{array}{l}349,7 \\
27\end{array}$ & $\begin{array}{l}4,40,3 \\
92\end{array}$ & $\begin{array}{l}5,26,0 \\
24\end{array}$ & $\begin{array}{l}5,13,2 \\
81\end{array}$ & $\begin{array}{l}5,38,2 \\
90\end{array}$ & $\begin{array}{l}4,80,0 \\
85\end{array}$ & $\begin{array}{l}5,31,9 \\
27\end{array}$ & $\begin{array}{l}5,38,2 \\
08\end{array}$ & $\begin{array}{l}5,11,6 \\
58\end{array}$ \\
\hline $\begin{array}{l}\text { 2- } \\
\text { Wlrs }\end{array}$ & $\begin{array}{l}7,052 \\
, 391\end{array}$ & $\begin{array}{l}7,872, \\
334\end{array}$ & $\begin{array}{l}7,249 \\
, 278\end{array}$ & $\begin{array}{l}7,437 \\
, 619\end{array}$ & $\begin{array}{l}93,70, \\
951\end{array}$ & $\begin{array}{l}1,17,6 \\
8,910\end{array}$ & $\begin{array}{l}1,34,0 \\
9,150\end{array}$ & $\begin{array}{l}1,37,9 \\
7,185\end{array}$ & $\begin{array}{l}1,48,0 \\
6,778\end{array}$ & $\begin{array}{l}1,60,0 \\
4,581\end{array}$ & $\begin{array}{l}1,64,5 \\
5,851\end{array}$ & $\begin{array}{l}1,75,8 \\
9,511\end{array}$ \\
\hline $\begin{array}{l}\text { G. } \\
\text { Total }\end{array}$ & $\begin{array}{l}8,906 \\
, 428\end{array}$ & $\begin{array}{l}10,12 \\
3,988\end{array}$ & $\begin{array}{l}9,654 \\
, 435\end{array}$ & $\begin{array}{l}9,724 \\
, 243\end{array}$ & $\begin{array}{l}1,22,9 \\
5,397\end{array}$ & $\begin{array}{l}1,54,8 \\
1,381\end{array}$ & $\begin{array}{l}1,73,6 \\
1,769\end{array}$ & $\begin{array}{l}1,77,9 \\
3,701\end{array}$ & $\begin{array}{l}1,84,2 \\
3,223\end{array}$ & $\begin{array}{l}1,97,5 \\
2,580\end{array}$ & $\begin{array}{l}2,04,6 \\
8,971\end{array}$ & $\begin{array}{l}2,18,6 \\
2,128\end{array}$ \\
\hline
\end{tabular}

Source: SIAM

\section{Importance of the Study}

Customer Satisfaction is a person's emotional feeling of the object, such as $\mathrm{good} / \mathrm{bad}$ or like/dislike, resulting from comparing a product's performance in relation to his or her product's expectations vs. perceptions based on customer attitude, product performance and service quality. Consumer's satisfaction may be a guide for monitoring and improving the current and potential performance of businesses (Zairi, 2000). Customer satisfaction can be defined in different ways - as a comparison of previously held expectations with perceived product or service performance (Homburg et al.. 2005, Anderson et al., 1994). Customer's satisfaction, leads to customer's loyalty, recommendation and repeat purchase (Wilson et al., 2008).

"Customer satisfaction is an ambiguous and abstract concept and the actual manifestation of the state of satisfaction will vary from person to person and product/service to product/service. The state of satisfaction depends on a number of both psychological and physical variables which correlate with satisfaction behaviors such as return and recommend rate. The level of satisfaction can also vary depending on other options the customer may have and other products against which the customer can compare the organization's products" (www.merchantaccounts.co).

The consumers are the focus activity of the company's marketing orientation, a research on the consumers' needs and their satisfaction is of a greater significance, and to develop a suitable strategy leading to a higher consumer's satisfaction. 


\section{Literature Review}

Computer-based searches were carried out on on-line databases include, EMERALD, JSTOR, and EBSCO using key words and wildcards symbols. Manual searches were conducted on journal articles' references identified through the online databases search.

Parinda V. Doshi (2016) selected 100 Asian paints customers in Vadodara, through convenient sampling, to analyse the relationship of customer satisfaction with product and services, it also examined the significance of product and services on satisfaction of the customer and thus observes overall satisfaction of the customer of Asian Paint. Relationship of product covered features, durability and variety; the relationship of services covered company services, and its dealers. Results had shown the positive relationship and effect on the product and services with satisfaction of the customers.

Petr Suchánek et al (2014) examined the influence of quality on customer satisfaction and business performance to generate profit in food industry. Satisfaction was examined by survey questionnaires, and the performance was measured by financial data. The sample consisted of 18 enterprises, and received 13,683 correctly and fully completed questionnaires. Authors found a correlation between the main factors, although partial results were due more factors mostly statistically insignificant. Suggests further research should thus examine the influence of the abovementioned factors adding price factor, on company performance as well as mutual relationships and links of individual factors so that it is possible to create a compact unit and a complex model comprising product quality, customer satisfaction and corporate performance.

Dr. Duggani Yuvaraju (2014) studied 100 Honda bikes customer samples through convenient sampling at Tirupati. Analyzed the data using chi-square, percentages and found significance difference between the preferable factors like mileage, pickup, price and design. Suggested more expenditure of TV advts, reduce bike cost, incentive dealers, set up dealer level service centres, home service and accurate service etc.,

Qadeer, Sara (2013) analysed the impact of service quality on customer satisfaction using five managerial interviews, two in Pakistani bank and three in Swedish bank. Findings reveal that quality of service does effect the customer satisfaction up to some certain level as both concepts are distinct and the relationship found between them is casual and the quality of service was affected by various factors such as human interaction, physical environment, value, price, performance etc. It is found that through proper planning and constant monitoring firms can develop effective strategies to improve quality levels and to retain their existing \& future customers. Suggested same research with an added variable, the impact of image, can be conducted by using quantitative methodology (customer surveys, questionnaire) to know about customer's perspective on quality and satisfaction.

Karolina Ilieska, (2013) carried out a survey on representative samples of Macedonian passenger and research services quality and customer satisfaction index (CSI) using ServQual model in the Macedonian passenger transport and found CSI 66\%< 80.4\% -borderline. Suggested, the marketing manager must make bigger efforts and create the new strategies for 
make better condition and develop the services quality like a base factor for passenger satisfactions.

Saraswathi S. (2008) analysed the Post-Sales Service customer satisfaction on 100 samples of various two-wheelers buyers of Hyderabad and Secunderabad. The study was presented in two parts: Part-I, on perception of customers on post-sale-service and Part-II, on ranking of respondents and satisfactory index on post-sale-service of two-wheeler automobile industry. Study found moderate mean values for some dimensions. Hence suggested manufacturers/ dealers to invest highly valuable service staff in the specific problem areas, i.e., specialised skills, satisfaction after the test ride and quality of service.

Zamazalová (2008) mentioned the key factors that affect customer satisfaction and also used to measure customer satisfaction. These factors were product (in terms of its quality, availability etc.); price (convenient payment conditions and others); services; distribution; and image of a product, used for their product differentiation, getting competitive advantage, barriers for switching and providing satisfaction to the customers.

Based on the thorough review of literature, there were evidences to show that product/ service quality, perceived value are strongly related to customer satisfaction and behavioural intentions in goods and services industry.

\section{Objectives of The Study}

This research study broadly aimed at identifying the impact of Customer Satisfaction on consumer outcomes. By improving the Customer Satisfaction (endogenous/ dependent variable) of select brands, inturn increases the demand and the market share of them in the region. Hence, the study had following research objectives:

1) To study the impact of select independent (exogenous) variables on Customer Satisfaction.

2) To examine the impact of demographic variables on Customer Satisfaction.

Based on the above objectives following two Null Hypotheses were formulated: $\mathbf{H}_{\mathbf{1}}$ : There is NO influence of exogenous variables (Safety features, Tech. Devt, Joint Venture, Heritage Design, and Corporate Social Responsibility) on Customer Satisfaction.

Sub Hypothesis: If an impact is found, the impact of each variable is the same.

$\mathbf{H}_{2}$ : There is NO influence of Demographic variables (14 items) on Customer Satisfaction.

Sub Hypothesis: If an impact is found, the impact of each variable is the same.

\section{Research Methodology}

In this exploratory research, Hero, Bajaj, Honda and TVS brand vehicles were selected for study and 600 two-wheeler consumers samples collected, using random sampling, in Hyderabad. A pilot study of 100 consumers of select four brands was collected through questionnaire and received 0.700 as reliability through Cronbach Alpha test. Later, other 500 two-wheeler consumers' data were collected through questionnaire, processed using SPSS version 23 software. For analysis descriptive statistics and non-parametric tests were used. References were noted in APA style. 


\section{Limitations}

Though every care was taken and all intervening factors considered still, the following limitations were inevitable.

1) The study was confined to two wheeler consumers in Hyderabad only.

2) The study was carried out, on a certain time period and hence it was influenced by prevailing factors during the period.

3) The study was the result of a sample size, considered to enable a smooth conduct and hence was not a total representation of the whole.

\section{Period of The Study}

The primary data was collected from January to May, 2017 and the secondary data was from 2005-17.

\section{Analysis and Results}

The following tables were the results of the Primary data analysis on SPSS software version 20.

\section{Hypothesis 1 Testing}

Table 2: Descriptive Statistics

\begin{tabular}{|l|l|l|l|}
\hline Variables & Mean & Std. Deviation & N \\
\hline Customer Satisfaction & 3.60 & 1.312 & 600 \\
\hline Safety (Accident Prevention) Features & 14.11 & 3.433 & 600 \\
\hline Technology Development (TD) & 17.75 & 3.970 & 600 \\
\hline Heritage (Antique) Design Preference (HD) & 13.35 & 3.606 & 600 \\
\hline Joint Venture Preference (JV) & 16.96 & 4.512 & 600 \\
\hline Corporate Social Responsibility (CSR) of the brand & 17.02 & 4.049 & 600 \\
\hline
\end{tabular}

Source: Primary data

Interpretation: Std. Deviation was 7.20 per cent means independents were intact.

Table 2: Correlations

\begin{tabular}{|l|l|l|l|l|l|l|l|}
\hline \multicolumn{2}{|c|}{ Variables } & $\begin{array}{c}\text { Customer } \\
\text { Satisfaction }\end{array}$ & $\begin{array}{c}\text { Safety } \\
\text { Acci. Prevn) } \\
\text { Features }\end{array}$ & $\begin{array}{c}\text { Tech. } \\
\text { Devt }\end{array}$ & $\begin{array}{c}\text { HD } \\
\text { Antique) } \\
\text { Preference }\end{array}$ & $\begin{array}{c}\text { Joint } \\
\text { Venture } \\
\text { Preference }\end{array}$ & $\begin{array}{c}\text { CSR } \\
\text { of the } \\
\text { brand }\end{array}$ \\
\hline \multirow{2}{*}{$\begin{array}{l}\text { Pearson } \\
\text { Correlation }\end{array}$} & $\begin{array}{l}\text { Customer } \\
\text { Satisfaction }\end{array}$ & 1.000 & .267 & .260 & .205 & .163 & .282 \\
\cline { 2 - 8 } & Safety Features & .267 & 1.000 & .623 & .285 & .290 & .582 \\
\cline { 2 - 8 } & Tech. Devt. & .260 & .623 & 1.000 & .385 & .334 & .615 \\
\cline { 2 - 8 } & $\begin{array}{l}\text { HD (Antique) } \\
\text { Pref }\end{array}$ & .205 & .285 & .385 & 1.000 & .417 & .378 \\
\cline { 2 - 8 } & JV Preference & .163 & .290 & .334 & .417 & 1.000 & .363 \\
\cline { 2 - 8 } & $\begin{array}{l}\text { CSR of the } \\
\text { brand }\end{array}$ & .282 & .582 & .615 & .378 & .363 & 1.000 \\
\hline $\begin{array}{l}\text { Sig. (1- } \\
\text { tailed) }\end{array}$ & $\begin{array}{l}\text { Customer } \\
\text { Satisfaction }\end{array}$ & & .000 & .000 & .000 & .000 & .000 \\
\hline
\end{tabular}




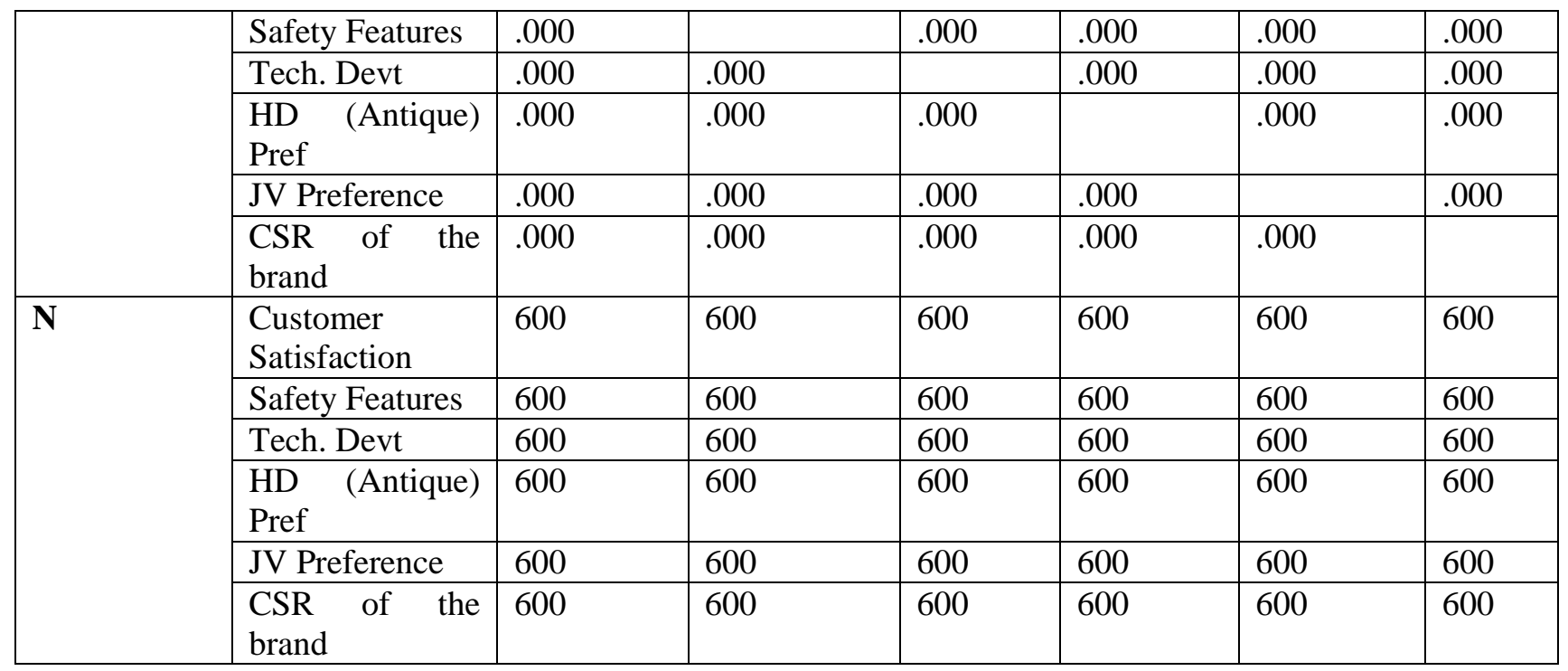

\section{Source: Primary data}

Interpretation: Linearity exists between endogenous and exogenous variables; correlation means (Sig. values) were close to 0.000 .

Table 3: Variables Entered/Removeda, b

\begin{tabular}{|l|l|l|l|}
\hline Model & Variables Entered & Variables Removed & Method \\
\hline 1 & $\begin{array}{l}\text { CSR of the brand, JV Preference, HD (Antique) } \\
\text { Preference, Safety (Accident Prevention) Features, } \\
\text { Technology Development }\end{array}$ & Enter \\
\hline a. Dependent Variable: Customer Satisfaction & \\
\hline b. All requested variables entered.
\end{tabular}

Table 4: Model Summary ${ }^{\mathrm{b}}$

\begin{tabular}{|l|l|l|l|l|l|}
\hline Model & R & R Square & Adjusted R Square & Std. Error of the Estimate & Durbin-Watson \\
\hline 1 & $.327^{\mathrm{a}}$ & .107 & .100 & 1.245 & 1.931 \\
\hline $\begin{array}{l}\text { a. Predictors: (Constant), CSR of the brand, JV Preference, HD (Antique) Preference, Safety (Accident } \\
\text { Prevention) Features, Technology Development }\end{array}$ \\
\hline \multicolumn{2}{|l}{ b. Dependent Variable: Customer Satisfaction } \\
\hline
\end{tabular}

Source: Primary data

Interpretation: In this Multiple-Linear-Regression, model summary and overall fit statistics studied. We predict Customer Satisfaction from Independent variables \{CSR of the brand, JV Preference, HD (Antique) Preference, Safety (Accident Prevention) Features and Technology Development . We found that the adjusted $\mathrm{R}^{2}$ of our model was 0.100 (standard adjusted $\mathrm{R}^{2}$ value must be above $0.50=50 \%$ ), with the $\mathrm{R}^{2}$ was 0.107 . This means that the linear regression explains 10.7 per cent of the variance data. It means that it is not a very good model but it cannot be dumped as well since the F-test shows that the cumulative effect is significant. In DurbinWatson (DW) test statistic, which is automatically produced with regression analysis, indicates presence of autocorrelation (must be between $d=1.5$ to 2.5 ), here it was $d=1.931$. Hence it shows that it does not suffer from autocorrelation and hence data can be used for regression analysis. 
Table 5: ANOVA $^{\mathrm{a}}$

\begin{tabular}{|c|c|c|c|c|c|c|}
\hline \multicolumn{2}{|c|}{ Model } & Sum of Squares & df & Mean Square & $\mathbf{F}$ & Sig. $(p)$ \\
\hline \multirow{3}{*}{1} & Regression & 110.491 & 5 & 22.098 & 14.247 & $.000^{\mathrm{b}}$ \\
\hline & Residual & 921.308 & 594 & 1.551 & & \\
\hline & Total & 1031.798 & 599 & & & \\
\hline \multicolumn{7}{|c|}{ a. Dependent Variable: Customer Satisfaction } \\
\hline
\end{tabular}

Source: Primary data

Interpretation: F-test of the Linear-Regression indicate that the overall model is statistically significant $(\mathrm{F}=14.247, p=0.000)$, has the null hypothesis that the model explains zero variance. Hence it was a good model (not a bad model). At least one independent variable was relevantly contributing, to be a good model.

Table 6: Coefficients ${ }^{\mathrm{a}}$

\begin{tabular}{|c|c|c|c|c|c|c|c|c|}
\hline \multirow{2}{*}{\multicolumn{2}{|c|}{ Model }} & \multicolumn{2}{|c|}{$\begin{array}{l}\text { Unstandardized } \\
\text { Coefficients }\end{array}$} & \multirow{2}{*}{$\begin{array}{c}\begin{array}{c}\text { Standardized } \\
\text { Coefficients }\end{array} \\
\text { Beta } \\
\end{array}$} & \multirow{2}{*}{$\mathbf{t}$} & \multirow{2}{*}{ Sig. } & \multicolumn{2}{|c|}{$\begin{array}{l}\text { Collinearity } \\
\text { Statistics }\end{array}$} \\
\hline & & B & Std. Error & & & & $\begin{array}{c}\text { Toleranc } \\
\text { e }\end{array}$ & VIF \\
\hline & (Constant) & 1.324 & .285 & & 4.645 & .000 & & \\
\hline & $\begin{array}{lll}\text { Safety } & \text { (Acci. } & \text { Prevn) } \\
\text { Features } & & \\
\end{array}$ & .045 & .020 & .119 & 2.270 & .024 & .547 & 1.827 \\
\hline 1 & Technology Development & .020 & .018 & .062 & 1.123 & .262 & .494 & 2.024 \\
\hline & HD (Antique) Preference & .032 & .016 & .087 & 1.932 & .054 & .744 & 1.344 \\
\hline & Joint Venture Preference & .007 & .013 & .022 & .509 & .611 & .769 & 1.301 \\
\hline & CSR of the brand & .043 & .017 & .134 & 2.513 & .012 & .528 & 1.893 \\
\hline
\end{tabular}

a. Dependent Variable: Customer Satisfaction

Source: Primary data

Interpretation: The information in the above tables also allows us to check for multicollinearity in our model. Tolerance should be $>0.1$ (or VIF <10) for all variables, which they are (VIF <5). Sig. values were nearer to 0.000 in CSR of the brand (0.012), and Safety features (0.024) reveals impact exists; whereas Heritage Design (Antique) preference (0.054), Technology Development (0.262) and Joint Venture Preference (0.611) reveals no impact. Standard ' $t$ ' value must be above 1.96 and Beta value below 0.05. To find out impact highest Standardised Beta value of CSR of the brand (0.134) and unstandardised Beta value of Safety features (0.045) leads to an extent of 4 units against 100 units, whereas HD (0.032), and Joint Venture preference (0.007) leads to 3 and $<1$ units against 100 units. There was no multi collinearity problem with the data, because VIF (Variance Inflation Factor) value was $<5$. 
Table 7: Collinearity Diagnostics

\begin{tabular}{|c|c|c|c|c|c|c|c|c|c|}
\hline \multicolumn{10}{|c|}{ Collinearity Diagnostics ${ }^{a}$} \\
\hline \multirow{2}{*}{\multicolumn{2}{|c|}{ Model }} & \multirow{2}{*}{ Eigenvalue } & \multirow{2}{*}{$\begin{array}{l}\text { Condition } \\
\text { Index }\end{array}$} & \multicolumn{6}{|c|}{ Variance Proportions } \\
\hline & & & & (Constant) & $\begin{array}{c}\text { Safety (Acci. } \\
\text { Prevention) } \\
\text { Features }\end{array}$ & $\begin{array}{l}\text { Tech. } \\
\text { Devt }\end{array}$ & $\begin{array}{c}\text { HD } \\
\text { (Antique) } \\
\text { Preference }\end{array}$ & $\begin{array}{c}\text { JV } \\
\text { Preference }\end{array}$ & $\begin{array}{c}\text { CSR of } \\
\text { the } \\
\text { brand }\end{array}$ \\
\hline \multirow[t]{6}{*}{1} & 1 & 5.838 & 1.000 & .00 & .00 & .00 & .00 & .00 & .00 \\
\hline & 2 & .056 & 10.221 & .00 & .13 & .04 & .26 & .28 & .04 \\
\hline & 3 & .039 & 12.200 & .00 & .00 & .00 & .66 & .62 & .00 \\
\hline & 4 & .027 & 14.756 & .94 & .02 & .01 & .03 & .08 & .13 \\
\hline & 5 & .022 & 16.239 & .03 & .60 & .00 & .03 & .02 & .67 \\
\hline & 6 & .018 & 18.015 & .02 & .26 & .95 & .02 & .00 & .16 \\
\hline
\end{tabular}

Source: Primary data

Interpretation: Condition Index was <30. Variance Proportion was highest (0.95) in Technology Development, whereas CSR of the brand (0.67), Heritage Design Preference (0.66), Joint Venture Preferences (0.62) and Safety features (0.60) were instrumental.

Table 8: Residuals Statistics

\begin{tabular}{|l|l|l|l|l|l|}
\hline \multicolumn{7}{|c|}{ Residuals Statistics $^{\mathbf{a}}$} \\
\hline & Minimum & Maximum & Mean & Std. Deviation & N \\
\hline Predicted Value & 2.24 & 4.60 & 3.60 & .429 & 600 \\
\hline Residual & -3.319 & 2.637 & .000 & 1.240 & 600 \\
\hline Std. Predicted Value & -3.166 & 2.315 & .000 & 1.000 & 600 \\
\hline Std. Residual & -2.665 & 2.118 & .000 & .996 & 600 \\
\hline a. Dependent Variable: Customer Satisfaction \\
\hline
\end{tabular}

Source: Primary data

Interpretation: From the Residual Statistics table and a histogram of the standardized residual was based on our model. Note that the unstandardized residuals should be a mean of zero (Assumptions of Linear Regression), and so do standardized predicted values and standardized residuals.
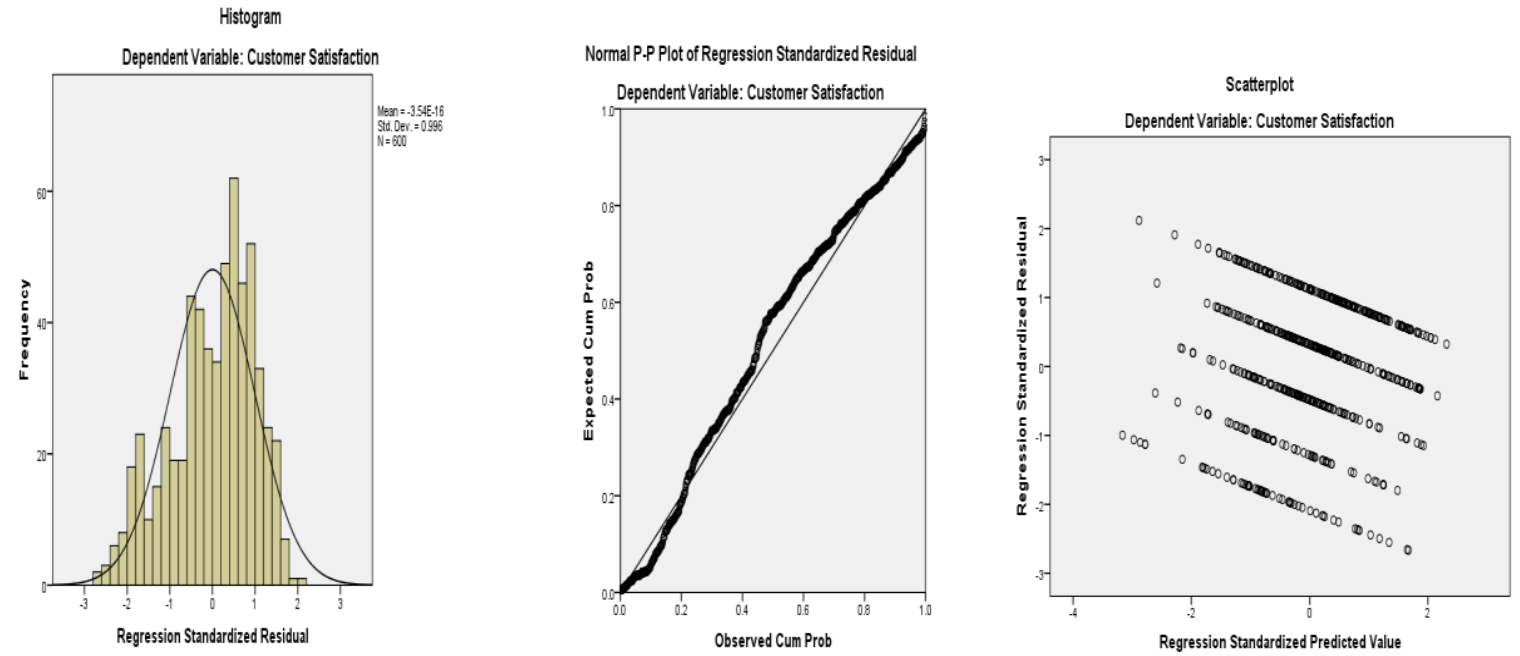
Interpretation: From the histogram we can see some values at the tail ends of the distribution of variable. The Normal Probability Plot shows, the distribution is normal, because we had seen the points to cluster around the horizontal line and the difference in the tail distributions of the P$P$ plot. Scatter plot indicates that there are no violations of the independence, homoscedasticity and linearity assumptions.

Hypothesis 1 Result: Overall from the above tables it was concluded that there was NO influence of Independent variables \{Safety (Accident Prevention) Features, Technology Development, HD (Antique) Preference, JV Preference, and CSR of the brand $\}$ on customer satisfaction. Hence Hypothesis 1 was rejected.

\section{Hypothesis 2 Testing}

The data was of non-linearity, hence the impact of demographic variables on Customer Satisfaction tested with Mann-Whitney test and Kruskal-Wallis Test against a standard sig. value of $<2.5 \%$.

Table 9: Mann-Whitney Test for Gender

\begin{tabular}{|l|l|c|r|r|}
\hline \multicolumn{5}{|c|}{ Ranks } \\
\hline \multicolumn{2}{|c|}{ Gender } & N & Mean Rank & Sum of Ranks \\
\hline Customer Satisfaction & Male & 372 & 306.18 & 113898.00 \\
\cline { 2 - 5 } & Female & 228 & 291.24 & 66402.00 \\
\cline { 2 - 5 } & Total & $\mathbf{6 0 0}$ & & \\
\hline
\end{tabular}

Source: Primary data

\begin{tabular}{|c|c|}
\hline \multicolumn{2}{|c|}{ Test Statistics ${ }^{\mathrm{a}}$} \\
\hline & Cust. Satisfaction \\
\hline Mann-Whitney $U$ & 40296.000 \\
\hline Wilcoxon $W$ & 66402.000 \\
\hline $\mathrm{Z}$ & -1.059 \\
\hline $\begin{array}{l}\text { Asymp. Sig (2-tailed) } \\
p\end{array}$ & .290 \\
\hline
\end{tabular}

The Ranks table is the first table that provides information regarding the output of the actual Mann-Whitney $U$ test. In this case, male had highest mean rank (306.18) compared to female mean rank (291.24). Test Statistics table data reveals that customer satisfaction in the female group ( $W=66402.000$ ) was statistically, significantly differ and was higher than the male group $(U=40296.000)$ and $p=0.290$ was higher than the standard ( $p$ value $<2.5 \%=0.025)$.

Interpretation: Gender had no impact on dependent variable (Customer Satisfaction). 
Table10: Mann-Whitney Test for most often, a pillion rider rides with me

\begin{tabular}{|c|l|c|r|r|}
\hline \multicolumn{5}{|c|}{ Ranks } \\
\hline \multicolumn{2}{|c|}{$\begin{array}{c}\text { Most often, a } \\
\text { pillion rider rides } \\
\text { with me: }\end{array}$} & N & \multicolumn{1}{c|}{$\begin{array}{c}\text { Mean } \\
\text { Rank }\end{array}$} & $\begin{array}{c}\text { Sum of } \\
\text { Ranks }\end{array}$ \\
\hline \multirow{2}{*}{$\begin{array}{c}\text { Customer } \\
\text { Satisfaction }\end{array}$} & Yes & 335 & 292.35 & 97938.50 \\
\cline { 2 - 5 } & No & 265 & 310.80 & 82361.50 \\
\cline { 2 - 5 } & Total & $\mathbf{6 0 0}$ & & \\
\hline
\end{tabular}

Source: Primary data

Test Statistics ${ }^{\text {a }}$
\begin{tabular}{|l|r|}
\hline \multicolumn{2}{|c|}{ Cust. Satisfaction $^{-1658.500}$} \\
\hline Mann-Whitney $U$ & 47938.500 \\
\hline Wilcoxon $W$ & -1.338 \\
\hline Z & .181 \\
\hline Asymp. Sig. (2-tailed) p & \\
\hline $\begin{array}{l}\text { a. Grouping Variable: } \\
\text { rider }\end{array}$ \\
\hline
\end{tabular}

The Ranks table shows mean ranks and sum of ranks for the grouping variable: Most often, a pillion rider rides with me tested for Yes or No groups. In this case, No group had highest mean rank (310.80) for Customer Satisfaction than Yes group mean rank (292.35). Test Statistics table data, it can be concluded that Customer Satisfaction in the No group ( $W=97938.500)$ was statistically, significantly higher than the Yes group $(U=41658.500)$ and $p=0.181$ was higher than the standard $(p$ value $<2.5 \%=0.025)$.

Interpretation: Pillion driver riding with consumer had no impact on Customer Satisfaction.

Table 11: Mann-Whitney Test for vehicle is shared with

\begin{tabular}{|c|c|c|c|c|}
\hline \multicolumn{5}{|c|}{ Ranks } \\
\hline \multicolumn{2}{|c|}{ Vehicle is shared with } & $\mathbf{N}$ & Mean Rank & Sum of Ranks \\
\hline \multirow[t]{3}{*}{ Customer Satisfaction } & Family members \& others & 450 & 299.83 & 134921.50 \\
\hline & Not shared, used myself & 150 & 302.52 & 45378.50 \\
\hline & Total & 600 & & \\
\hline
\end{tabular}

Test Statistics ${ }^{\mathrm{a}}$

\begin{tabular}{|c|c|}
\hline \multicolumn{2}{|c|}{ Test Statistics ${ }^{\mathrm{a}}$} \\
\hline & C Stsfetn \\
\hline Mann-Whitney $U$ & 33446.500 \\
\hline Wilcoxon $W$ & 134921.500 \\
\hline $\mathrm{Z}$ & -.171 \\
\hline Asymp. Sig. (2-tailed) & .865 \\
\hline a. Grouping Variable: & shared with \\
\hline
\end{tabular}

Source: Primary data

The Ranks table shows mean ranks and sum of ranks for the grouping variable vehicle is shared with, tested for Family members and others or Not shared, used by myself groups. In this case, Not shared, used myself had highest mean rank (302.52) for Customer Satisfaction than family members and others (299.83) mean rank. Test Statistics table data conclude that Customer 
Satisfaction in the Family members and others $(W=134921.500)$ was statistically, significantly higher than the Not shared, used by myself $(U=33446.500)$ and $p=0.865$ was higher than the standard $(p$ value $<2.5 \%=0.025)$.

Interpretation: Vehicle sharing had no impact on Customer Satisfaction.

Table 12: Mann-Whitney Test for Gear Status

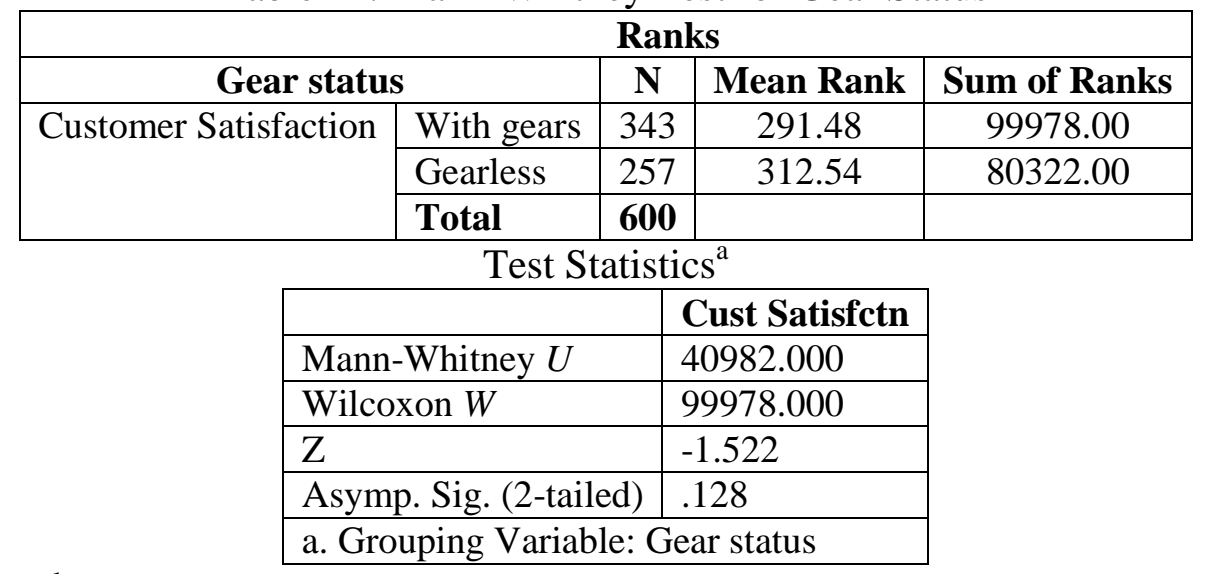

Source: Primary data

The Ranks table shows mean ranks and sum of ranks for the grouping variable vehicle is shared with, tested for with Gears and Gearless. In this case, Gearless had highest mean rank (312.54) for Customer Satisfaction than with gears (291.48) mean rank. Test Statistics table data results suggest, there was statistically difference between the underlying distributions of the Customer Satisfaction, with gears and gearless. Gearless $(W=99978.000)$ was statistically, significantly higher than with gears $(U=40982.000)$ and $p=0.128$ was higher than the standard ( $p$ value $<2.5 \%=0.025)$.

Interpretation: Gear status had no impact on Customer Satisfaction.

Table 13: Mann-Whitney Test for Engine Capacity

\begin{tabular}{|l|l|c|r|r|}
\hline \multicolumn{5}{|c|}{ Ranks } \\
\hline \multicolumn{2}{|c|}{ Engine capacity } & N & Mean Rank & Sum of Ranks \\
\hline Customer Satisfaction & Below 126 cc & 384 & 309.29 & 118766.50 \\
\cline { 2 - 5 } & Above 126 cc & 216 & 284.88 & 61533.50 \\
\cline { 2 - 5 } & Total & $\mathbf{6 0 0}$ & & \\
\hline
\end{tabular}

Test Statistics ${ }^{\text {a }}$
\begin{tabular}{|l|l|}
\hline \multicolumn{1}{|c|}{ Cust. Satisfctn $^{-1}$} & 38097.500 \\
\hline Mann-Whitney $U$ & 61533.500 \\
\hline Wilcoxon $W$ & -1.711 \\
\hline Z & .087 \\
\hline Asymp. Sig. (2-tailed) & .08 \\
\hline a. Grouping Variable: Engine capacity \\
\hline
\end{tabular}

Source: Primary data 
The Ranks table shows mean ranks and sum of ranks for the grouping variable: Engine Capacity for below 126cc and above $126 \mathrm{cc}$. In this case, below $126 \mathrm{cc}$ had highest mean rank (309.29) for Customer Satisfaction than with above 126 cc (284.88) mean rank. Test Statistics table data results suggest, there was statistically difference between the underlying distributions of the Customer Satisfaction, below $126 \mathrm{cc}$ and above $126 \mathrm{cc}$. Below $126 \mathrm{cc}(W=61533.500)$ was statistically, significantly higher than, above 126cc $(U=38097.500)$ and Asymptotic Sig. value $(p=0.087)$ was higher than the standard ( $p$ value $<2.5 \%=0.025)$.

Interpretation: Engine Capacity had no impact on Customer Satisfaction.

Table 14: Mann-Whitney Test for Distance from home to Service centre

\begin{tabular}{|c|l|r|r|r|}
\hline \multicolumn{5}{|c|}{ Ranks } \\
\hline Distance from home to service center & N & Mean Rank & Sum of Ranks \\
\hline \multirow{3}{*}{ Customer Satisfaction } & Close by & 249 & 245.33 & 61087.00 \\
\cline { 2 - 5 } & Far-off & 251 & 255.63 & 64163.00 \\
\cline { 2 - 5 } & Total & $\mathbf{5 0 0}$ & & \\
\hline
\end{tabular}

Test Statistics ${ }^{\mathrm{a}}$

\begin{tabular}{|l|l|}
\hline \multicolumn{1}{|c|}{ Results/ Outputs } & Cust. Satisfaction \\
\hline Mann-Whitney $U$ & 29962.000 \\
\hline Wilcoxon $W$ & 61087.000 \\
\hline Z & -.822 \\
\hline Asymp. Sig. (2-tailed) & .411 \\
\hline a. Grouping Variable: Distance from home \\
\hline
\end{tabular}

Source: Primary data

The Ranks table shows mean ranks and sum of ranks for the grouping variable: Distance from home to service center, tested for close-by and far-off. In this case, far-off had highest mean rank (255.63) for Customer Satisfaction than close by (245.33) mean rank. Test Statistics table data suggests, there was statistically difference between the underlying distributions of the Customer Satisfaction, close-by and far-off. Far-off $(W=61087.000)$ was statistically, significantly higher than close-by $(U=29962.000)$ and $p=0.411$ was higher than the standard ( $p$ value $<2.5 \%$ $=0.025$ ).

Interpretation: Distance from home to service centre had no impact on Customer Satisfaction.

Table 15: Kruskal-Wallis Test for Age

\begin{tabular}{|c|c|c|c|}
\hline \multicolumn{4}{|c|}{ Ranks } \\
\hline \multicolumn{2}{|l|}{ Age } & $\mathbf{N}$ & Mean Rank \\
\hline \multirow[t]{5}{*}{ Customer Satisfaction } & $18-30 \mathrm{yrs}$ & 416 & 308.43 \\
\hline & $31-45$ yrs & 132 & 281.01 \\
\hline & $46-60 \mathrm{yrs}$ & 39 & 287.71 \\
\hline & $61-75$ yrs & 13 & 283.19 \\
\hline & Total & 600 & \\
\hline
\end{tabular}


Test Statistics ${ }^{\text {a }}$

Source: Primary data

\begin{tabular}{|l|l|}
\hline & Cust. Satisfaction \\
\hline Chi-Square $\left(\chi^{2}\right)$ & 3.077 \\
\hline degrees of freedom $(\mathrm{df})$ & 3 \\
\hline Asymptotic Significance $(p)$ & .380 \\
\hline a. Grouping Variable: Age \\
\hline
\end{tabular}

The Ranks table results indicate that there were statistically significant differences among the four classes of Age. Lowest Mean rank represents highest value; 31-45 years (281.01), 61-75 years (283.19), 46-60 years (287.71) and 18-30 years (308.43) were ranked 1, 2, 3, and 4 respectively. 31-45 years were ranked high. Test Statistics table data suggests, Asymptotic Sig. value $(p=0.380)$ was higher than the Sig. value $<2.5 \%=0.025$.

Interpretation: Age had no impact on Customer Satisfaction.

Table 16: Kruskal Wallis Test for Economic Status

\begin{tabular}{|c|c|c|c|}
\hline \multicolumn{4}{|c|}{ Ranks } \\
\hline \multicolumn{2}{|c|}{ Economic Status } & $\mathbf{N}$ & Mean Rank \\
\hline \multirow[t]{4}{*}{ Customer Satisfaction } & Middle Class & 379 & 308.85 \\
\hline & Upper Middle Class & 170 & 290.18 \\
\hline & Rich & 51 & 272.86 \\
\hline & Total & 600 & \\
\hline
\end{tabular}

Source: Primary data

\begin{tabular}{|l|l|}
\multicolumn{2}{c|}{ Test Statistics $^{\mathrm{a}}$} \\
\hline & Cust. Satisfaction $^{\circ}$ \\
\hline Chi-Square & 2.968 \\
\hline df & 2 \\
\hline Asymp. Sig. & .227 \\
\hline a. Grouping Variable: Economic status \\
\hline
\end{tabular}

The Ranks table results indicate that there were statistically significant differences among the three classes of Economic status. Lowest Mean rank represents highest value; Rich (272.86), Upper-Middle (290.18) and Middle (308.85) were ranked 1, 2 and 3 respectively. Rich were ranked high for their branded product purchases. Test Statistics table data suggest, Asymptotic Sig. value $(p=0.227)$ was higher than the standard (Sig. value $<2.5 \%=0.025)$.

Interpretation: Economic status had no impact on Customer Satisfaction.

Table 17: Kruskal Wallis Test for Formal Education

\begin{tabular}{|c|c|c|c|}
\hline \multicolumn{4}{|c|}{ Ranks } \\
\hline \multicolumn{2}{|c|}{ Formal Education } & $\mathbf{N}$ & Mean Rank \\
\hline \multirow[t]{6}{*}{ Customer Satisfaction } & Below 10 & 39 & 306.37 \\
\hline & $10-12$ & 119 & 277.05 \\
\hline & Graduate & 284 & 317.04 \\
\hline & PG \& Above & 136 & 293.85 \\
\hline & \begin{tabular}{|l|} 
Professional \\
\end{tabular} & 22 & 244.45 \\
\hline & Total & 600 & \\
\hline
\end{tabular}


Source: Primary data

\begin{tabular}{|l|l|}
\multicolumn{2}{c}{ Test Statistics $^{\mathrm{a}}$} \\
\hline & Customer Satisfaction $^{\mathrm{a}}$ \\
\hline Chi-Square & 7.807 \\
\hline df & 4 \\
\hline Asymp. Sig. & .099 \\
\hline a. Grouping Variable: Formal Education \\
\hline
\end{tabular}

The Ranks table results indicate that there were statistically significant differences among the five classes of Formal education. Lowest Mean rank represents highest value; Professionals (244.45), 10-12 grade (277.05), PG \& above (293.85), below 10 (306.37) and Graduate (317.04) were ranked 1, 2, 3, 4 and 5 respectively. Professionals were ranked high. Test Statistics table data suggests, Asymptotic Sig. value $(p=0.099)$ was higher than the standard (Sig. value $<2.5 \%$ $=0.025$ ).

Interpretation: Education had no impact on Customer Satisfaction.

Table 18: Kruskal Wallis Test for Two-Wheeler Brand Owned

\begin{tabular}{||l|l|r|c|}
\hline \multicolumn{4}{|c|}{ Ranks } \\
\hline \multicolumn{2}{|c|}{ Two-wheeler brand owned } & \multicolumn{1}{c|}{ N } & Mean Rank \\
\hline Customer Satisfaction & Hero & 164 & 294.30 \\
\cline { 2 - 4 } & Bajaj & 98 & 291.64 \\
\cline { 2 - 4 } & Honda & 187 & 300.35 \\
\cline { 2 - 4 } & TVS & 85 & 305.12 \\
\cline { 2 - 4 } & Others & 66 & 323.53 \\
\cline { 2 - 4 } & Total & $\mathbf{6 0 0}$ & \\
\hline
\end{tabular}

Source: Primary data

\begin{tabular}{|c|c|}
\hline \multicolumn{2}{|r|}{ Test Statistics $^{\mathrm{a}}$} \\
\hline & Customer Satisfaction \\
\hline Chi-Square & 1.806 \\
\hline df & 4 \\
\hline Asymp. Sig. & .771 \\
\hline \multicolumn{2}{|c|}{ a. Kruskal Wallis Test } \\
\hline $\begin{array}{l}\text { b. Grouping } \\
\text { owned }\end{array}$ & Jariable: Two-wheeler brand \\
\hline
\end{tabular}

The Ranks table results indicate that there was statistically significant difference among the five classes of two wheeler brand owned. Lowest Mean rank represents highest value; Customer Satisfaction of Bajaj (291.64), Hero (294.30), Honda (300.35), TVS (305.12) and others (323.53) were ranked 1, 2, 3, 4 and 5 respectively. Bajaj motorcycles were ranked high. Test Statistics table data suggests, Asymptotic Sig. value $(p=0.771)$ was higher than the standard (Sig. value $<2.5 \%=0.025)$.

Interpretation: Two wheeler brand owned had no impact on Customer Satisfaction. 
Table 19: Kruskal Wallis Test for Occupation

\begin{tabular}{|c|c|c|c|}
\hline \multicolumn{4}{|c|}{ Ranks } \\
\hline \multicolumn{2}{|c|}{ Occupation } & $\mathbf{N}$ & Mean Rank \\
\hline \multirow[t]{6}{*}{ Customer Satisfaction } & Student & 327 & 252.24 \\
\hline & Professional & 70 & 260.11 \\
\hline & Govt. Employee & 23 & 212.72 \\
\hline & Private Employee & 61 & 249.19 \\
\hline & Business & 19 & 235.13 \\
\hline & Total & 500 & \\
\hline
\end{tabular}

Source: Primary data

\begin{tabular}{|c|c|}
\hline \multicolumn{2}{|c|}{ Test Statistics $^{a b}$} \\
\hline & Customer Satisfaction \\
\hline Chi-Square & 2.286 \\
\hline df & 4 \\
\hline Asymp. Sig. & .683 \\
\hline \multicolumn{2}{|c|}{ a. Kruskal Wallis Test } \\
\hline b. Grouping & ariable: Occupation \\
\hline
\end{tabular}

The Ranks table results indicate that there was statistically significant difference among the five classes of Occupation. Lowest Mean rank represents highest value; Govt. employee (212.72), Business (235.13), Private Employee (249.19), Students (252.24) and Professional (260.11) were ranked 1, 2, 3, 4 and 5 respectively. Govt. employees were ranked high. Test Statistics table data suggest, Asymptotic Sig. value $(p=0.683)$ was higher than the standard (Sig. value $<2.5 \%$ $=0.025$ ).

Interpretation: Occupation had no impact on Customer Satisfaction.

Table 20: Kruskal Wallis Test for Length of usage

\begin{tabular}{|c|l|c|c|}
\hline \multicolumn{4}{|c|}{ Ranks } \\
\hline \multicolumn{2}{|c|}{ Length of usage } & N & Mean Rank \\
\hline \multirow{3}{*}{$\begin{array}{c}\text { Customer } \\
\text { Satisfaction }\end{array}$} & $1-3$ yrs & 240 & 248.17 \\
\cline { 2 - 4 } & $3-5$ yrs & 143 & 263.39 \\
\cline { 2 - 4 } & Above 5 yrs & 117 & 239.53 \\
\cline { 2 - 4 } & Total & $\mathbf{5 0 0}$ & \\
\hline
\end{tabular}

Source: Primary data

Test Statistics ${ }^{\text {a }}$
\begin{tabular}{|l|l|}
\hline \multicolumn{2}{|c|}{ Customer Satisfaction $^{\mid}$} \\
\hline Chi-Square & 1.993 \\
\hline df & 2 \\
\hline Asymp. Sig. & .369 \\
\hline a. Kruskal Wallis Test \\
\hline b. Grouping Variable: Length of usage \\
\hline
\end{tabular}

The Ranks table results indicate that there was statistically significant difference among the three classes of length of Usage. Lowest Mean rank represents highest value; Above 5 years (239.53), 1-3 years (248.17) and 3-5 years (263.39) were ranked 1, 2, and 3 respectively. Above 
5 years were ranked high. Test Statistics table data suggest, Asymptotic Sig. value $(p=0.369)$ was higher than the standard $(p$ value $<2.5 \%=0.025)$.

Interpretation: Length of usage of vehicle had no impact on Customer Satisfaction.

Table 21: Mann-Whitney Test for Marital Status

\begin{tabular}{|c|c|c|c|c|}
\hline \multicolumn{5}{|c|}{ Ranks } \\
\hline \multicolumn{2}{|c|}{ Marital Status } & $\mathbf{N}$ & Mean Rank & Sum of Ranks \\
\hline \multirow[t]{3}{*}{ Customer Satisfaction } & Married & 121 & 221.50 & 26801.50 \\
\hline & Unmarried & 356 & 244.95 & 87201.50 \\
\hline & Total & 477 & & \\
\hline
\end{tabular}

Source: Primary data

Test Statistics ${ }^{\mathrm{a}}$
\begin{tabular}{|l|l|}
\hline \multicolumn{1}{|c|}{} & Customer Satisfaction $^{\circ}$ \\
\hline Mann-Whitney $U$ & 19420.500 \\
\hline Wilcoxon $W$ & 26801.500 \\
\hline Z & -1.668 \\
\hline Asymp. Sig. (2-tailed) & .095 \\
\hline a. Grouping Variable: Marital Status \\
\hline
\end{tabular}

The Ranks table shows mean ranks and sum of ranks for the grouping variable: Marital Status tested for Married and Unmarried. In this case, Unmarried had highest mean rank (244.95) for Customer Satisfaction than married (221.50) mean rank. Test Statistics table data results suggest, there was statistically difference between the underlying distributions of the Customer Satisfaction, for married and unmarried. Unmarried ( $W=26801.500)$ was statistically, significantly higher than married $(U=19420.500)$ and Asymptotic Sig. value $(p=0.095)$ was higher than the standard $(p$ value $<2.5 \%=0.025)$.

Interpretation: Marital status had no impact on Customer Satisfaction.

Table 22: Mann-Whitney Test for Brand Recall:

\begin{tabular}{|c|c|c|c|c|}
\hline \multicolumn{5}{|c|}{ Ranks } \\
\hline Brand Recall (Vehicle was repaired or replaced by Orgn) & $\mathbf{N}$ & Mean Rank & Sum of Ranks \\
\hline Customer Satisfaction & Yes & 287 & 306.50 & 87964.50 \\
\cline { 2 - 5 } & No & 313 & 295.00 & 92335.50 \\
\cline { 2 - 5 } & Total & $\mathbf{6 0 0}$ & & \\
\hline
\end{tabular}

Source: Primary data

\begin{tabular}{|l|l|}
\multicolumn{2}{|c|}{ Test Statistics ${ }^{\mathrm{a}}$} \\
\hline Mann-Whitney $U$ & Customer Satisfaction \\
\hline Wilcoxon $W$ & 43194.500 \\
\hline $\mathrm{Z}$ & 92335.500 \\
\hline $\begin{array}{l}\text { Asymp. Sig. } \quad(2- \\
\text { tailed) }\end{array}$ & -.839 \\
\hline \begin{tabular}{l} 
a. Grouping Variable: Brand Recall \\
\hline
\end{tabular}
\end{tabular}


The Ranks table shows mean rank and sum of ranks for the grouping variable Brand Recall: tested for Yes or No classes. In this case, Yes class had highest mean rank (306.50) for Customer Satisfaction than with No (295.00) mean rank. Test Statistics table data results suggest, there was statistically difference between the underlying distributions of the Customer Satisfaction, yes or no of Brand Recall. Yes option ( $W=92335.500)$ was statistically, significantly higher than No option $(U=43194.500)$ and Asymptotic Sig. value $(p=0.402)$ was higher than the standard $(p$ value $<2.5 \%=0.025)$.

Interpretation: Brand Recall had no impact on Customer Satisfaction.

\section{Hypothesis 2 Result}

Decision, since p-value was $<0.025$, we reject the null hypothesis. There was no impact of (Demographic variables) Gender, Pillion driver, Gear status, Engine capacity, Distance from home to service centre, Vehicle sharing, Age, Economic status, Education, vehicle Brand owned, Occupations, Length of usage, Marital status and Recall of vehicles on Customer Satisfaction.

\section{Findings}

The following observations were found on Customer Satisfaction

1) Linearity exists between endogenous and exogenous variables, correlation means (Sig values) were close to 0.000

2) Std. Adjusted $\mathrm{R}^{2}$ value was 0.100 (must be $>50 \%$ ), hence it was a very good model.

3) F-test results of Linear-Regression were $\mathrm{F}=14.247, p=0.000$. Hence it was a good model (not a bad model). At least one exogenous variable was relevant and contributing, to be a good model.

4) Sig. values were nearer to 0.000 in CSR of the brand (0.012), and Safety features (0.024) reveals impact exists; whereas Heritage Design (Antique) preference (0.054), Technology Development (0.262) and Joint Venture Preference (0.611) reveals no impact. Standard ' $t$ ' value must be above 1.96 and $p$ - value below 0.05. To find out impact highest Standardised Beta value of CSR of the brand (0.134) and unstandardised Beta value of Safety features (0.045) leads to an extent of 4 units against 100 units, whereas HD (0.032), and Joint Venture preference (0.007) leads to 3 and $<1$ units against 100 units. There was no multi collinearity problem with the data, because VIF (Variance Inflation Factor) value was $<5$.

5) Condition Index was <30. Variance Proportion was highest (0.95) in Technology Development, whereas Heritage Design Preference and Joint Venture Preferences were instrumental.

6) The data was of non-linearity, the impact of 14 demographic variables on Customer Satisfaction tested with Mann-Whitney test and Kruskal-Wallis test against Significance (p) value of $<2.5 \%(0.025)$ and found 14 variables had NO impact on Customer Satisfaction. 


\section{Conclusion}

After the two mentioned hypotheses testing, which were rejected based on collected quantitative data. Hence both the Objectives were met. To confirm those results, 20 Senior (citizens) consumers were contacted for qualitative input, which proved the same.

\section{Future/Research Implications}

Our research should be seen as a preliminary attempt at addressing an issue that has important implications for services marketing theory and practice. Any preliminary attempt will involve a number of limitations. However, acknowledgement of these limitations suggests new directions for future studies.

1) Why the Chinese (world's largest two-wheeler industry) two-wheeler firms haven't been able to enter the Indian markets successfully? What challenges a new entrant has to face in the industry? Can Indian auto companies, manufacture in China using Chinese suppliers base to dent Chinese companies and export to other countries for the "lower end customers" market share? Can the answer be applied to other industries to safeguard Indian industries (avoid/ control Chinese competition)?

2) Develop South-India centred cluster(s), due to present Industry concentration in NorthIndia (NCR-Delhi: Noida, Gurgaon, Manesar; Mumbai: Aurangabad, Nashik, Pune; Gujarat: Halol, Sanand; Kolkata; Bengaluru).

\section{Managerial Implications}

Based on collected data analysis, manufacturer has to focus more on Technological Developments, Safety features, and CSR activities, but less on Heritage (Antique) Design Preference and Joint Ventures.

\section{Originality/Value}

From practical angle, companies must improve Customer Satisfaction to enjoy the substantial competitive and economic advantages provided by it.

\section{Acknowledgements}

The scholar thanks Prof. Appalayya Meesala for helping with SPSS, and Prof. Shankar Chatterjee for publishing guidance.

\section{References}

[1] Anderson, E. W., Formelo, C., Lehmann, D. R. (1994). Customer Satisfaction, Market Share, and Profitability: Findings from Sweden. Journal of Marketing, Vol. 58, No. 3, p. 53-66.

[2] Doshi , Parinda V. (2016) Role of product and services on satisfaction of customers: A Case study of Asian Paints. International Journal of Research in Commerce \& Management 1, Vol. 7, Issue-06. ISSN 0976-2183

[3] Dr. Duggani Yuvaraju \& Prof. S. Durga Rao (2014) Customer Satisfaction towards Honda Two Wheelers: A Case Study in Tirupati. OSR Journal of Business and Management, Vol. 16(5). Ver. I (May), PP 65-74 
[4] Homburg et al. (2005) Do satisfied Customers Really Pay More? A Study of the Relationship between Customer Satisfaction and Willingness to Pay. Journal of Marketing 69(2): 84-96.

[5] Karolina Ilieska, (2013) Customer Satisfaction Index - as a Base for Strategic Marketing Management, TEM Journal, 2(4), 327-331.

[6] Ministry of Heavy Industries and Public Enterprises. (2006). Automotive Mission Plan 20062016, Govt of India, New Delhi.

[7] Petr Suchánek, Jiří Richter, Maria Králová (2014) Customer Satisfaction, Product Quality and Performance of Companies, Review of Economic Perspectives - Národohospodárský Obzor, Vol. 14 (4), pp. 329-344, DOI: 10.1515/revecp-2015-0003

[8] Qadeer, Sara (2013) Service Quality \& Customer Satisfaction: A case study in Banking Sector. Masters thesis. November - 2013, Second Cycle, University of Gavle, Sweden

[9] Saraswathi S. (2008). Customer satisfaction on post-sales service with reference to Two-Wheeler Automobile Industry. The ICFAI Journal of Consumer Behaviour, III ( 2). June 2008, Hyderabad: The ICFAI University Press. India. pp 32-48.

[10] Wilson, A., Zeithamal, V.A., Bitner, M.J., Gremler, D.D., (2008). Services Marketing. McGrawHill Edn.

[11] Www.merchantaccounts.co/merchant-account-glossary.htm\#C Accessed on 19 January, 2018. At $09.52 \mathrm{pm}$

[12] Zairi, M., 2000. Managing Customer Satisfaction: A best practice perspective. TQM Mag. 12 (6), 389-394.

[13] Zamazalova, M. (2008). Spokojenost zákazníka. Acta Oeconomica Pragensia, Vol. 16, No. 4, p. 76-82.

*Corresponding author.

E-mail address: maakhan1155@gmail.com/madhu4m@ gmail.com 